\title{
Motivation and innovation role of school's principal in improving teacher professionalism
}

\author{
Nellitawati Nellitawati ${ }^{*}$ \\ Universitas Negeri Padang \\ *)Corresponding author, ఏe-mail: nellitawati@gmail.com
}

\begin{abstract}
The main purpose of this study is to determine the motivation and innovation role of principals in improving the professionalism of teachers at SMK Negeri in Padang City. The design of mixed methods. A total of 261 teachers were included as respondents to answer the distributed questionnaires, and a total of 12 respondents were included in the interview, consisting of principals and expert teachers. The findings indicate that the main role in improving the professionalism of teachers is still at a moderate level. This study also shows that the role of principal motivation and innovation has a significant influence in improving the professionalism of teachers in teaching and learning. Based on qualitative results determined that the role of principal motivation and innovation is an important factor to improve the professionalism of teachers. This study emphasizes that the role of principal motivation and innovation in enlightening teacher professionalism is an absolute factor.
\end{abstract}

Keywords: motivation and innovation role, principal, teacher professionalism

How to Cite: Nellitawati. (2018). Motivation and innovation role of school's principal in improving teacher professionalism. Couns-Edu: International Journal of Counseling and Education, 3(2): pp. 48-56. DOI: https://doi.org/10.23916/0020180313520

This is an open access article distributed under the Creative Commons Attribution License, which permits unrestricted use, distribution, and reproduction in any medium, provided the original work is properly cited. (C2017 by author and Indonesian Counselor Association (IKI).

\section{Introduction}

The main thing that must be done to improve the quality of human resources in Indonesia is to improve the quality of education. However, the quality of education in Indonesia is still relatively low with the percentage of 14,6 \% (Ayu, 2014). This case can be seen from Indonesia's low human development index when compared with other countries around the world. Indonesia's human development index is ranked 113 out of 188 countries (Nugroho, 2017). It means Indonesian's human development is in medium level.

One important aspect of the effort to improve the quality of education is to improve the quality of teachers by increasing teacher competency by maximizing the competency requirements of teachers to professional teachers. Professional teachers mean that the teacher must have four competencies, namely pedagogical competence, competency, social competence and professional competence. Teacher competence is the ability and skill of teachers in carrying out their duties for the smooth process of teaching and learning that takes place in the booths of the darling, as well as determines the stage of achievement of teaching and learning process of high quality (Kodama, 2016; Vanhear, 2016). Therefore, the development of teacher competence needs to be done well (Misbah, Gulikers, Maulana, \& Mulder, 2015), because teachers are the decisive factor in achieving educational brilliance. Although there are a good curriculum and complete ease, but if there is no teacher who has high competence, then the brilliance of education is difficult to achieve (Prestridge, 2012). To be able to improve their competence, a teacher 
must learn continuously while teaching, so that they can improve the skills and skills needed to carry out their duties (Kitaabati, 2012).

Although there has been Minister of National Education Regulation No. 13 year 2007 regarding Standard of School Principals explaining that the competence of school principal is important and is the main factor to achieve school organization's glory in improving the quality of education, but in Indonesia especially, in Padang the issue of the weakness of the role of principal in leading the school is not New issues. The main issue is the lack of leadership competence in the management of principal schools consequently the quality of education participate berk and down (Kitaabati, 2012). In this case Yukl (2013) expressed that in the leadership of the principal there are some weaknesses. The main disadvantage is the stere leadership leaders who tend to refer to the bureaucratic model as a result they forget the role as leaders who need to menjited komited subordinates to the school. Thus, they tend to elicit formal rules that have autorative leadership stances, overemphasize academic achievement and set the role of a leader who can capitalize the skinned human beings for achievement of educational goals.

Research about the influence of the principal's managerial ability and the factors that influence the work motivation on the performance of slb teachers in subang regency by Karweti (2010) shows principals play an important role in school leadership. Then, study of the role of school counselors (Bryan, Day-Vines, Griffin, \& Moore-Thomas, 2012; Khansa, 2015), which focuses on the role of school-goers in Madrasah Aliyah towards teacher achievement in enhancing the quality of education found that the role of school principal has a significant relationship to teacher competence, when teacher competence mempuyai positive relationship With the quality of teaching and learning. Referring to the case, the reviewer conducted an investigation into the role of school principal in enhancing the competence of teachers in Vocational High School (SMK) Negeri Padang Indonesia. Therefore, to achieve the richness of education required teachers to have high skills and competencies holistically, namely the competence pedagogy, keperibadian, professional, and social. Mastery of competence is very important to improve the quality of teaching and learning, and so on the matlamat to produce quality education may be achieved. Furthermore, the teacher's educational stage is also one of the factors influencing the low competence of teachers (Karweti, 2010). Furthermore, Mu'Min (2011) adds about the role of headmaster in improving teacher professionalism in SDI al-Ihsan bamboo apus Pamulang. The results of his research show that the implementation of the role of the principal is well enough. in this case the role to the school in order to improve the professionalism of teachers is very dominant. empowerment of faculty, staff, improvement of learning facilities, supervision of learning and teaching process all of which can run well enough, through the role of the school school's principal.

In addition, the mastery of the material and lesson methods are still lacking and the commitment of teachers in performing their duties has not been maximum (Naderi Anari, 2012). Furthermore, the low quality and competence of teachers is caused by the absentee playing his/her maximum role in performing the task. Because the role of the school principal as educators, administrators, pentadbir, leaders, supervisors, motivators and innovators have not been implemented properly then certainly have a negative impact on the competence of teachers in carrying out their duties (Yudhistira, 2013).

Based on the background of this study problem that teacher professsionalism is one of the benchmarks of the quality of education (Muhson, 2004). In addition, teacher competence has an important role in the teaching and learning process (Bustari, 2010). Therefore, to carry out quality learning, teachers need to master competencies as required by Law No. RI. 14 (2005), PP 19 years (2005) and BSNP (2006). However, the lack of role of principal as educators, administrators, pentadbir, leaders, supervisors, motivators and innovators will have an impact on the declining competence of teachers (Renstra Kemendiknas, 2011). Because of the lack of maximal role in running the task, it will have an impact on the decrease of teacher competence (Yudhistira, 2013). Thus the low role of the role of the counselor also leads to a low level of teacher competence.

The role of school principal should do guidance to the teacher well so that teachers can complete the job well and get maximum results. In carrying out its duties, the role of principal role is caused by several factors including the stage of education and the period of his ritual. Those who have high education stages may perform their duties well and vice versa likewise that the lower stage of education of 
the principal then the pursuit of performing their duties is also not maximum (Ahmad, 2014; Setiyati, 2014). Although the study run by Settaraming, Rahman and Tahir (2012) found that some of the authors who have higher education stages are still not positively related to their ability to perform the task. Is there a real difference in the role of the principal in carrying out his duties to follow the educational stage? Therefore, the reviewer will analyze the same difference between the role of the leader as a leader in his educational stage.

Determining the role of principal role in improving teacher competence and competence of Vocational High School teachers in the City of Padang. Determining the same there is a difference in the role of teachers and the competence of Vocational High School teachers in the city of Padang based on demography (stage of education and period of ritual). Determine the problems faced by principal and teachers of State Vocational High School in Padang City in improving teacher competence. Determining the role of the principal who becomes a predictor of the competence of Vocational High School teachers in the city of Padang.

\section{The Innovation Role of Principal}

Hallinger and Moosung Lee (2013) describe that the pursuit of success in school is inseparable from the role of the school counselors to give new ideas and to support teachers to have high knowledge, skill and motivation. Consequently Crow and Peterson (2014) expressed that the schoolteacher as an innovator has the power to foster a matlamat to encourage and activate all the staff in the organization he leads to carry out his tasks as well as possible. School counselors should have new creative and thoughtful thoughts to facilitate interpreting the school's vision and mission as well as the ability of the school counselors to implement their role (Soleimani, Nader dan Tebyanian, 2011).

According to Kidwall et al. (2013), the principal as an innovator should have a role to transfer knowledge supported by the sharing of cases that are shared together to find new ways of solving any current issues. So the principal does not appear as a 'one man show' and rivals may produce a staff that is able to describe the concept possessed by the principal. It is therefore desirable if the counselor has a delegative and integrative role. A delegative role model means that school leaders can run to their subordinates for a particular job. While integrative principal is principal who have keystayaan in integrating various activities in school. In addition, the school's principal must be capable of scientific rational and objective thinking (Bass \& Bernard, 2006).

\section{The Motivation Role of Principal}

Nyaribo, Misuko; Prakash, Ajai and Edward (2012) describe that school administrations or organizations need to provide motivation as a staff with a gesture for the staff to be aware of the many benefits that will be obtained if we run our duties with passion. As an aging motivator it is necessary to have the right principle or strategy in order to provide reserves to followers to work properly. This role requires the constituent to create a good working/school environment atmosphere, a pleasant working atmosphere, a well-preserved discipline culture, a memorable gift to educational personnel (Bass \& Bernard, 2006).

Motivation is one of the factors that can influence teacher competency stage. Working feet with high work motivation will result in good quality work, because their tasks / work are done in earnest and heartfelt. In harmony with the opinion expressed by Mangkunegara (2012) which states that factors that affect the competence of teachers that is; (I) factors that include the potential capability of IQ and the reality of reality, and (ii) motivation factors can also be formed from the attitude (attitude) an organizational staff.

Robert L. Martis and John H. Jackson (2012) suggests that there are several factors that affect the stage of one's competence; (1) motivation, (2) received support, (3) the realization of the work they undertake, and (4) their relationship with the organization. In additon, Murwati (2013) also suggested that factors that may affect the stage of one's competence is a factor of motivation. After that, Dhermawan, Sudibya, dan Utama (2012) stated that motivation is part of an element that may influence one's competence in performing its duties. Furthermore, Wardana (2013) also states that motivation is defined as the willingness of a person to show a high effort to achieve the organization's matlamat. 


\section{Teacher Professionalism}

Professionalsm of teacher is a competency that should be possessed by teachers in implementing the teaching and learning process in the dung room. Teachers are required to understand their learning materials well. Besides teachers are required to master the teaching materials, the teacher must also comprehensively comprehend and deepen the areas of expertise he or she taught that includes (1) concepts, structures, methods of knowledge, (2) learning materials in accordance with the school curriculum, (3) the relationship between related subjects, (4) the application of concepts in daily life, (5) competing professionally in a global context without abandoning the national cultural values (Depkeu, 2005). Being a professional teacher can not be done quickly and not something easy. Before becoming an expert, the teacher must go through several stages of being a novice to advanced, competent, provident, and finally becoming an expert (Wardana, 2013).

A personal capability of a teacher who has elements of noble, steady, stable, and mature, wise and wise, be tauladan, reaping own achievements and awaken themselves and religious. Basically learning is a change of behavior. In addition, teachers must have certain personal qualities that include responsibility, dignity, self-reliance, and discipline (Mulyasa, 2009). Social competence is a teacher's ability to connect with the surrounding community. Such cultivation is the endeavor in communicating as well as oral and written, using functional communication technology, associating with students, co-workers, parents or guardians, and getting along well with the surrounding community (Sudrajat, 2009). Besides the existing social and personal competencies, the most important and essential things teachers need to master are idealism and ideals. Idealism to be achieved through education such as teaching seriousness, interact or communicate directly with the community and express ideas through writing, especially in the article ihmiah (Sukmadinata, 2014).

\section{Method}

The research design used in this research is mixed method design (Murwati, 2013). The population is a group of people who have the quality and specific characteristics established by the researcher (Sugiyono, 2010). Researchers determine all teachers who teach in 10 vocational schools (SMK) Negeri Padang - Indonesia as the population in this study for quantitative analysis. The total population of teachers at SMK Negeri 10 Padang, according to the Ministry of Education in the city of Padang is 865 people. Based on a population that is large enough, especially for vocational teachers is needed in certain ways to select only part of the total population. The principles of sample problems and the population is a matter of representation. Mechanical sampling should be selected appropriately so that the selected sample of the population may represent the characteristics of the population. When the characteristics of the sample was representative of the characteristics of the population, the conclusion can be made on the population (Sugiyono, 2010).

The determination of the number of samples multiplied by the total study population, 30 per cent of the total population of 865 multiplied by 30 per cent equals 261 teachers. All teachers selected as samples were then asked to provide answers about the role of school principals in enhancing the competence of teachers, as well as to assess the impact of the role of school principals to improve the competence of teachers in public vocational school in the city of Padang. Sampling technique used in this study is the technique of random sampling (random sampling). This technique is used to determine which teachers are selected for this study because all teachers have the same probability to be elected as a sample. According to Creswell (2014) that specifies the number of samples in the qualitative requirements are based on respondents' answers saturation interviewed. Researchers in this case chose six principals and six teachers to be interviewed as compliant with the number of interviews and the respondents expected that the answer will be found already aging. To determine the qualitative sample in this study we used purposive sampling technique (Sibona \& Walczak, 2012; Suen, Huang, \& Lee, 2014). This technique means that the study is intended to obtain information about the principal role in enhancing the competence of teachers. Thus the main requirement is that the principals of vocational schools in the city of Padang and some teachers considered eligible necessary in this study as experience in the service for at least five years and have attended workshops required. Principals and teachers are also selected principals and teachers who have outstanding performance based on the reports received from the Education Department of the city of Padang, Indonesia. 


\section{Quantitative Data Analysis}

In order to gain an appropriate research results, the researchers chose to adopt a joint investigation concurrent design between quantitative and qualitative disproportionately i.e Concurrent Embedded Mixed Method Design. The choice of method is because in this method it is possible to collect data simultaneously and a study showing that both take advantage of the results of quantitative research data and data from qualitative research (Creswell, 2010). The purpose of using a combination of methods is not balanced is to build strength between quantitative and qualitative research studies, as well as address the shortcomings inherent in both methods (Gay, 2006). There are many benefits to be gained from combining quantitative and qualitative research, which provides a broader understanding of the issues contained in the study (Creswell, 2010). In line with the research done, then there are two types of survey data analysis, ie the analysis of quantitative and qualitative data. Especially for quantitative data analysis, the survey group B and group C, researchers are using the application program of Statistical Package for the Social Sciences (SPSS) for Windows 21.0. In this case study analysis of the data was performed using descriptive analysis and multivariate analysis at the 0.05 significance level (alpha $<0.05$ ). Explanation of the use of both types of statistical analysis is shown in the following description.

Descriptive statistics were used to describe the study as a reflection of the prevailing situation on the object under investigation and are not intended to take any conclusions (Revelle, 2017; Weiss \& Weiss, 2012). Quantitative analysis was performed using frequency table's description. The results are described in the form of frequency, percentage and average. Low level of mean score is mean score of 1.00 to 2.33, and moderate level is 2.34 to 3.66 of mean score and the last is high level when the mean score is around 3.67 to 5.00 (Sugiyono, 2010). Use inferential statistical analysis aimed to test the hypothesis. Correlation and regression statistical techniques are used to measure testing the hypothesis. This test is intended to test every hypothesis that has been previously established. In accordance with the nature of the test hypotheses, then in this case there will be two possibilities to test, namely whether the null hypothesis of the study is accepted, or rejected. Testing based on a 95 percent confidence level (alpha 5 percent) means that the relationship between variables is significant or $a=0.05$. If a significant value $>0.05$ then the null hypothesis is accepted, otherwise if a significance value $<0.05$, the null hypothesis is rejected.

Quantitative Data Analysis

Qualitative data analysis of a continuous process that requires continuous reflection on the data, ask questions of analytical questions. Qualitative data analysis can involve compiling data from interviews, interpret, and report their findings simultaneously and together. Qualitative analysis is a technique for data collection using interviews to the parties concerned, so that the type of data is the data type categories (Bryman \& Bell, 2015; Sgier, 2012; Vaismoradi, Turunen, \& Bondas, 2013). The researchers started from the general to the specific in merging data analysis, (Creswell, 2012). To facilitate researchers in running data analysis after data collection in the field concerned with the study in vocational schools in the city of Padang, the researchers used a thematic analysis with the help of cross-case analysis (Seijger, Chris; Dewulf, Geert; Tatenhove, Jan Van; Otter, 2015). The data were analysed by cross-case analysis in order to facilitate the analysis of qualitative data because the process is performed initially by making the coding of data and then make a percentage of each frequency responder.

\section{Results and Discussions}

The result shows that the respondent school teacher in the city of Padang City was good because of the level of education is quite good with lots of scholars and doctors. There tenure majority of teachers who have more experience and teachers also attended the workshop as a whole.

\section{Descriptive Analysis}

Descriptive results show that the overall level of State High School principal role in Padang is simple. The findings show the role of the principal is simple because it has a mean value of 3:50 with a standard deviation of .659. This finding means that the overall level is still modest principal role. Therefore, that needs to improve in the future. This study found that the principal role as an innovator and motivator are also at a moderate level only. Because the mean value of the principal role as an innovator is 
3:55 with a standard deviation of .742 and as a motivator has a simple mean value of 3:53 with a standard deviation of .650. This finding also means that the principal role in enhancing the competence of teachers in terms of innovation and motivation they need to be improved. Both the principal roles in this perception of teacher in majority are on a scale of 4 points but also found many teachers give the perception that disagrees with scale three points. The teacher professionalism found in the moderate level only since the mean value was 3.64 with a standard deviation of .579. Frequency, the teacher professionalism was 140 (53.6 per cent). This finding meant that the personality of the professionalism of teachers and professionals is essential for the success of enhanced external students of the students.

\section{Inferential Analysis}

The result of multiple linear regression analysis showed that the overall effect of the principal roles of teacher professionalism is significant because of the significant $\mathrm{F}(12,984)$ is 0.000 . The principal results of the significant role of teacher professionalism is significant and the fifth hypothesis cannot be accepted or rejected as sig 0.000 less than the value of 0.05 .

Table 1: Regression Analysis Results

\begin{tabular}{lccc}
\hline Independent variables & $\boldsymbol{\beta}$ & $\boldsymbol{t}$ & Sig \\
\hline Constanta & 3.338 & 20.871 & .000 \\
\hline Innovator Role & .297 & 3.103 & .002 \\
\hline Motivator Role & .219 & 2.330 & .021 \\
\hline Dependent Varable
\end{tabular}

Dependent Variable: Teacher Professionalism

$\begin{array}{lll}\operatorname{adj} \mathrm{R}^{2} & =.287 & \\ \mathrm{R} & =.514 & \mathrm{~F}=12.984 \\ \mathrm{R}^{2} & =.309 & \mathrm{sig}=.000\end{array}$

Table 1 shows that the principal role as an innovator is a significant influence on teacher professionalism as $t$ value of 3,103 with the significant level of .002 . This can mean that the role of the principal innovation is essential in improving the professionalism of teachers. There appear also that the role of the principal motivations on teachers' professionalism is significant at the level of .021 with a $t$ value of 2,330. That means that with the motivation of the principals it will have an impact on the improvement of professionalism of teachers. Both principal roles are important function in the process of improving the ability of teachers in terms of professional.

\section{Qualitative Findings}

Qualitative analysis of this study provides a thematic analysis by cross case analysis to ensure that the opinion of the principal and teachers at each theme is whether in the role of principal and teacher professionalism. The findings by professional teachers, then there are four aspects of teacher respondents indicated that this one is simple and there are two stages of respondents said that teachers have low level in terms of professionalism. That means that the whole can say that the level of teacher's professionalism is gradually moderate related to the interviews findings of the respondents. Although teachers already certified but still modest professional level there is even a low level. This finding is very clear to policy makers in particular to the departments concerned to take into account in improving the quality of teachers certified. Based on the opinions of respondents said an interview that professional teachers are still modest, it means that professional teachers need to get serious attention from the government to improve the level of professionalism of teachers this one.

Overall, it seems that the principal motivators are experiencing serious difficulties in carrying out his duties at the school. The principal role in improving the professionalism of teachers certainly have some problems because some principal is rarely follow up workshops or self-study can add to his knowledge in the exercise of his duties. Another problem is the addition of individual principal problems of the teachers who are less aware of the importance of following a workshop to gain knowledge and skills. Indeed, these problems are not a serious problem because the principal can divide the inquiry in resolving problems with sharing to the deputy principal and to the teachers themselves. Up hoped that the professionalism of teachers could be increase because of the support of the school principal as a motivator. One example of motivation that can give is "a person who stops learning is the owner of the past, but the 
study is the owner of the future." This means that if teachers do not learn it will be left behind and do not have success in the present and future but has a grim past."

Overall, it seems that the principal as an innovator is not experiencing serious difficulties in leading the school. However of course there are the problems but it is not a severe problem because the principal is able to look for a proper solution by first making the rules and standards that can support the administration in carrying out his task. In order to improve the professionalism of teachers should be not become a difficult thing since the teacher can join a workshop or short course. The problem occurs when teachers do not support the principal to make innovation such as teachers do not want to learn to upgrade their information and skill.

\section{Conclusions}

The study found that the level of competence of teachers is at a moderate level and so is the principal role at a moderate level. The roles of school principals in improving the professionalism of teachers have been demonstrate with significance levels of statistical. This means that the principal role of motivation and innovation to increase the professionalism of teachers. This study can provide real implications on improving the professionalism of teachers in particular how the quality of teachers required for the successful outcome. At least, these findings may be a reference to the principal in improving the professionalism of teachers. Further research could also have implications on the government in particular how the government provides rules and policies to support an increase in teachers' professionalism.

\section{References}

Ahmad, S. (2014). Problematika kurikulum 2013 dan kepemimpinan instruksional kepala sekolah. Jurnal Pencerahan, 8(2).

Ayu, L. R. (2014). Kualitas Pendidikan Indonesia. Retrieved from https://www.kompasiana.com/raralestari25/kualitas-pendidikan-diindonesia_54f995f6a3331118568b45bb

Bass, Bernard, M. . R. R. E. (2006). Transformational Leadership (Second edi). New Jersey: Lawrence Erlbaum Associates, Inc., Publishers.

Bryan, J., Day-Vines, N. L., Griffin, D., \& Moore-Thomas, C. (2012). The disproportionality dilemma: Patterns of teacher referrals to school counselors for disruptive behavior. Journal of Counseling \& Development, 90(2), 177-190.

Bryman, A., \& Bell, E. (2015). Business research methods. Oxford University Press, USA.

Bustari, M. (2010). Kepemimpinan Transformasional Kepala Sekolah dalam Meningkatkan Kinerja Organisasi. UNY.

Creswell, J. W. (2014). Research Design_ Qualitative, Quantitative, and Mixed Method Approaches. California: Sage Publications, Inc.

Crow, G.M. dan Peterson, K. D. (2014). Principals Role in Restructuring School. Leadership and Management -. Politics and Governance.

Depkeu. (2005). Undang-Undang Nomor 14 Tahun 2005. Retrieved January 12, 2018, from www.sjdih.depkeu.go.id/fullText/2005/14TAHUN2005UU.html

Dhermawan, A. A. N. B., Sudibya, I. G. A., \& Utama, I. W. M. (2012). Pengaruh motivasi, lingkungan kerja, kompetensi, dan kompensasi terhadap kepuasan kerja dan kinerja pegawai di lingkungan kantor Dinas Pekerjaan Umum Provinsi Bali. Matrik: Jurnal Manajemen, Strategi Bisnis Dan Kewirausahaan.

Gay, L. R. (2006). Educational Research: Compentencies for Analysis and Applications. New Jersey: Pearson Prentice Hall.

Hallinger, P. dan L. M. (2013). Exploring Principal Capacity to Lead Reform of Teaching and Learning Quality in Thailand. International Journal of Educational Development, 33; 305-31.

Karweti, E. (2010). Pengaruh kemampuan manajerial kepala sekolah dan faktor yang mempengaruhi motivasi kerja terhadap kinerja guru SLB di Kabupaten Subang. Jurnal Penelitian Pendidikan, 11(2), 77-89.

Kemendiknas, R. (2003). Kemendiknas 2010-2014. Kementerian Pendidikan Nasional. 
Khansa, R. (2015). Teachers' Perceptions toward School Counselors in Selected Private Schools in Lebanon. Procedia-Social and Behavioral Sciences, 185, 381-387.

Kidwell, C. S., Jahan, R., Gornbein, J., Alger, J. R., Nenov, V., Ajani, Z., ... Schwamm, L. H. (2013). A trial of imaging selection and endovascular treatment for ischemic stroke. New England Journal of Medicine, 368(10), 914-923.

Kitaabati. (2012). Permendiknas RI No 19 Tahun 2005 Standar Nasional Pendidikan. Retrieved from http://kitaabati.blogspot.co.id/2012/12/permendiknas-ri-no-19-tahun-2005.html

Kodama, M. (2016). The role of educational leadership on participation in the Costa Rican national program of science and technology fairs at Escuela Colòn in San José Oeste. University of Southern California.

Mangkunegara., A. A. P. (2012). Evaluasi Kinerja Sumber Daya Manusia. Bandung: Refika Aditama.

Mathis, R. L. dan J. H. J. (2012). Manajemen Sumber Daya Manusia. Jakarta: Salemba Empat.

Misbah, Z., Gulikers, J., Maulana, R., \& Mulder, M. (2015). Teacher interpersonal behaviour and student motivation in competence-based vocational education: Evidence from Indonesia. Teaching and Teacher Education, 50, 79-89.

Mu'Min, A. (2011). Peranan kepala sekolah dalam meningkatkan profesionalisme guru di SDI al-Ihsan bambu apus Pamulang.

Muhson, A. (2004). Meningkatkan Profesionalisme Guru: Sebuah Harapan. Jurnal Ekonomi Dan Pendidikan, Volume $2 \mathrm{~N}$.

Mulyasa, E. (2009). Manajemen Berbasis Sekolah. Bandung: Rosdakarya.

Murwati, H. (2013). Pengaruh sertifikasi profesi guru terhadap motivasi kerja dan kinerja guru di smk negeri se-Surakarta. Jurnal Pendidikan Bisnis Dan Ekonomi (BISE), 1(1), 1-10.

Naderi Anari, N. (2012). Teachers: emotional intelligence, job satisfaction, and organizational commitment. Journal of Workplace Learning, 24(4), 256-269.

Nugroho, I. (2017). Peringkat Indeks Pembangunan Manusia RI Turun, Ini Kata Pemerintah. Retrieved from https://finance.detik.com/berita-ekonomi-bisnis/d-3455970/peringkat-indeks-pembangunanmanusia-ri-turun-ini-kata-pemerintah

Nyaribo, Misuko; Prakash, Ajai; dan Edward, O. (2012). Motivators of Choosing a Management Course: A Comparative Study of Kenya and India. The International Journal of Management Education, Elsevier.

Prestridge, S. (2012). The beliefs behind the teacher that influences their ICT practices. Computers \& Education, 58(1), 449-458.

Revelle, W. R. (2017). psych: Procedures for personality and psychological research.

Seijger, Chris; Dewulf, Geert; Tatenhove, Jan Van; Otter, H. S. (2015). Towards Practitioner-Initiated Interactive Knowledge Development For Sustainable Development: A Cross-Case Analysis Of Three Coastal Projects. Global Environmental Change, 34 (2015).

Setiyati, S. (2014). Pengaruh kepemimpinan kepala sekolah, motivasi Kerja, dan budaya sekolah terhadap kinerja guru. Jurnal Pendidikan Teknologi Dan Kejuruan, 22(2), 200-206.

Settaraming, Mohd., Rahman, Anuar Abdul dan Tahir, L. M. (2012). Peranan Kepimpinan Principal Sekolah Dalam Membina Pembelajaran Berpasukan Guru Di Sekolah Menengah Daerah Soppeng. Jurnal Pendidikan Malaysia, 37(2): 1-9.

Sgier, L. (2012). Qualitative data analysis. An Initiat. Gebert Ruf Stift, 19-21.

Sibona, C., \& Walczak, S. (2012). Purposive sampling on Twitter: A case study. In System Science (HICSS), 2012 45th Hawaii International Conference on (pp. 3510-3519). IEEE.

Soleimani, Nader dan Tebyanian, E. (2011). A Study of the Relationship between Principals' Creativity and Degree of Environmental Happiness in Semnan High Schools. International Conference on Education and Educational Psychology (ICEEPSY 2011), Procedia 2.

Sudrajat, A. (2009). Peraturan Pemerintah No. 74 Tahun 2008 tentang Guru. Retrieved January 11, 2018, from https://akhmadsudrajat.wordpress.com/2009/01/16/peraturan-pemerintah-no-74-tahun-2008tentang-guru/

Suen, L.-J. W., Huang, H.-M., \& Lee, H.-H. (2014). A comparison of convenience sampling and purposive sampling. Hu Li Za Zhi, 61(3), 105.

Sugiyono. (2010). Metode Penelitian Pendidikan: Pendekatan Kuantitatif, Kualitatif, dan R \&D. Bandung: Alfabeta.

Sukmadinata, N. S. (2014). Pengembangan Kurikulum Teori dan Praktek. Bandung: Remaja Rosdakarya. 
Vaismoradi, M., Turunen, H., \& Bondas, T. (2013). Content analysis and thematic analysis: Implications for conducting a qualitative descriptive study. Nursing \& Health Sciences, 15(3), 398-405.

Vanhear, J. (2016). Merging metacognitive tools for use in higher education to facilitate meaningful learning. Staffordshire University.

Wardana, D. S. (2013). Motivasi berprestasi dengan kinerja guru yang sudah disertifikasi. Jurnal Ilmiah Psikologi Terapan, 1(1), 98-109.

Weiss, N. A., \& Weiss, C. A. (2012). Introductory statistics. Pearson Education London.

Yudhistira, D. (2013). Menulis Penelitian Tindakan Kelas Yang Apik. Gramedia Widiasarana Indonesia.

Yukl, G. A. (2013). Leadership in organizations. Pearson Education India. 